\title{
IN VITRO ANTI-INFLAMMATORY AND ANTIOXIDANT ACTIVITIES OF HINGULESWARA RASA- BASED HERBOMINERAL FORMULATIONS
}

\section{ABHISHEK CHATTERJEE ${ }^{1}$, DILEEP SINGH BAGHEL ${ }^{1 *}$, AMIT MITTAL ${ }^{1}$, SAURABH SINGH ${ }^{1}$, BIMLESH KUMAR ${ }^{1}$, NARENDRA KUMAR PANDEY ${ }^{1}$, SACHIN KUMAR SINGH ${ }^{1}$, TAMILVANAN ${ }^{1}{ }^{1}$, SHRUTI CHOPRA ${ }^{2}$, AMIT BHATIA ${ }^{3}$, ANAND KUMAR CHAUDHARY ${ }^{4}$}

\begin{abstract}
${ }^{1}$ School of Pharmaceutical Science, Lovely Professional University, Punjab, India. ${ }^{2}$ Amity Institute of Pharmacy, Amity University, Uttar Pradesh, India. ${ }^{3}$ Department of Pharmaceutical Sciences and Technology, Maharaja Ranjit Singh Punjab Technical University, Punjab, India. ${ }^{4}$ Department of Rasa Shastra and Bhaishjya Kalpana, (Ayurvedic Pharmaceutics), Faculty of Ayurveda, Institute of Medical Sciences, Banaras Hindu University, Uttar Pradesh, India. Email: baghel_12@rediffmail.com
\end{abstract}

Received: 16 March 2018, Revised and Accepted: 09 July 2018

ABSTRACT

Objective: The aims of the present investigation were to develop the herbal and/or herbomineral formulations of Hinguleswara rasa and to compare their anti-inflammatory and antioxidant activities, in vitro, with that of standard drug samples.

Methods: This study was an interventional investigation in three samples: In the first sample, Hinguleswara rasa (HR1) was prepared as per methodology described in Rasatarangini using Shuddha Hingula (10 g), Shuddha Vatsanabha (10 g), and Pippali (10 g). In the second and third sample, respectively, Hinguleswara rasa was prepared by replacing Shuddha Hingula with Kajjali where Kajjali made from Hingulotha parada and Sodhita parada constitutes two varieties of Hinguleswara rasa, i.e. HR2 and HR3. In vitro antioxidant activity was studied using 2,2-diphenyl-1-picrylhydrazyl, and the absorbance was recorded at $517 \mathrm{~nm}$. For evaluating the in vitro anti-inflammatory studies, the inhibition of albumin denaturation technique was performed.

Results: The results showed that the formulation of Hinguleswara rasa has shown dose-dependent activity which was observed in $100 \mu \mathrm{g}$ concentration. HR1, HR2, and HR3 showed $36.11,17.22$, and $16.11 \%$ radical scavenging activity.

Conclusion: It could be concluded that the changes made in the formulations did not affect the in vitro anti-inflammatory and antioxidant effects of the herbomineral formulations.

Keywords: Anti-inflammatory, Antioxidant, 2,2-diphenyl-1-picrylhydrazyl, Hinguleswara rasa, Rasashastra, Rasaushadhis, Herbomineral formulations. (c) 2018 The Authors. Published by Innovare Academic Sciences Pvt Ltd. This is an open access article under the CC BY license (http://creativecommons. org/licenses/by/4. 0/) DOI: http://dx.doi.org/10.22159/ajpcr.2018.v11s2.28535

\section{INTRODUCTION}

Rasashastra is the science dealing with Rasa (mercury) minerals, metals, herbal poisons, and substances of aquatic origin. Its establishment starts from the medieval period wherein the human beings adapt the changing of lifestyle. Instead of active physical work throughout the day, a sedentary lifestyle slowly occupies in every day working of human beings. This ultimately results in the deterioration of normal physiological activities of body tissues. The most established physiological activities of healthy body tissues include fighting against inflammation and free radical formation inside the human body. To restore these two normal physiological activities of healthy body tissues, the use of herbo-mineral-based formulations is one of the lucrative options in modern-day medical practice [1-7].

Rasashastra flourished because of the qualities of Rasaushadhis such as quick action, small dose, palatability, and high efficacy [1-7]. Hinguleswara rasa comprises three ingredients, i.e. Shuddha Hingula, Shuddha Vatsanabha, and Pippali, and it is known for its activity against rheumatoid arthritis (RA) [8]. Inflammation is a complex process associated with pain, and it involves many changes such as the increase of vascular permeability, protein denaturation, and membrane alteration. Denaturation of proteins is one of the main causes of inflammation when cells are damaged by microbes and physical or chemical agents. Often, the inflammation in tissue is associated with cardinal signs such as redness, pain, heat, swelling, and loss of function in the injured area [9-16]. RA is a chronic inflammatory disease, characterized by irreversible joint disorder associated with destruction of bones as well as cartilage, which further may bring about serious morbidity. In addition, the chronic inflammation associated with RA can increase one's risk of atherosclerosis, which is a recognizable cause of mortality with the cardiovascular failure [17-22]. Moreover, atherosclerosis associated with RA progresses rapidly without the conventional risk factors such as hypertension, diabetes mellitus, or obesity [15]. On the other hand, free radicals or responsive oxygen species (ROS) can make harm the tissue. The wellsprings of ROS in the organic framework are cell digestion and ecological sources. Cell reinforcements are the blend of exogenous or endogenous in nature which either keep the age of poisonous oxidants or capture any that are created and inactivate them and in this way obstruct the spread of chain response delivered by these oxidants [14-32].

The aims of present investigation were to develop the herbo-mineral formulations of Hinguleswara rasa and to compare their antiinflammatory and antioxidant activities, in vitro, with that of standard drug samples.

\section{MATERIALS AND METHODS}

Materials

Hingula, Vatsanabha, and Pippali were purchased from the local market of Jalandhar and sent for authentication to Central Research Facility, Analytical Laboratory (AYUSH Approved ASU Drugs Testing Laboratory), Shri B.M.K Ayurveda Mahavidyalaya, Post Graduate Studies and Research Centre, KLE University, Shahapur, Belagavi-03, Karnataka. The authentication sample code no. is CRF/13/994-998 and its reference number no. is CRF/116/2013. 2,2-diphenyl-1-picrylhydrazyl 
(DPPH) purchased from Loba Chemie Pvt. Ltd., Mumbai, India. Ethanol was obtained from Changshu Yangyuan Chemicals, China. All other chemicals and reagents used were of analytical grade. Triple distilled water was used throughout the study.

\section{Preparation of Pippali churna}

Accurately weighed Pippali (200 g) was size-reduced with the help of household mixer and the obtained powder was passed through sieve no. \#100 to produce Sukshma churna (fine powder) [33].

\section{Shodhana and churinkaran of Vatsanabha}

Shodhana of Vatsanabha (300 g) was done by swedan method [8] in Dolayantra with godugdha as a liquid media for specified time period $(6 \mathrm{~h})$. After that, the outer cover was removed and kept it under sunlight for drying. Accurately weighed Shuddha Vatsanabha (190 g) was sizereduced with the help of grinder and the obtained powder was passed through sieve no. \#100 to produce Sukshma churna (fine powder) $(150 \mathrm{~g})$.

\section{Shodhana of Hingula}

By utilizing the 7 Bhavana procedure of Nimbu Swarasa, the Shodhana of Hingula (300 g) was developed [34]. After Shodhan, the color of Hingula has become bright red. About $15 \mathrm{~g}$ weight was gained during processing as shown in Table 1.

\section{Shodhana of Gandhaka}

The Gandhaka (200 g) was taken in a Khalva Yantra and powdered, and Dhalana process was done using godugdha as a liquid media for 7 times [33, 34]. After that, the Gandhaka was washed with warm water, dried, and powdered (179 g).

\section{Extraction of parada from Hingula}

The Hingula (200 g) was taken in a Khalva Yantra and powdered. After that, it was triturated with Nimbu Swarasa to form pellets. Following drying of the pellets in room temperature conditions, the pellets were arranged in the bottom of an earthen vessel, and then, another vessel was placed over it invertedly and the joints were sealed with mud smeared cloth. The whole setup was then heated in Tivragni for $6 \mathrm{~h}$, and after swangsheetikaran, the mercury was scratched off the surface and washed with warm water [33,34]. The total weight of mercury obtained after washing is $65.68 \mathrm{~g}$.

\section{Preparation of Hinguleswara rasa-based herbomineral formulation} (HR1)

The Hinguleswara rasa was prepared as per the methodology mentioned in Rasatarangini using the Shuddha Hingula (10 g), Shuddha Vatsanabha (10 g), and Pippali (10 g). All materials were taken in powdered form and triturated to form a homogeneous mixture. Then, the Bhavana procedure was performed with the addition of water into the produced homogenous mixture to form a semisolid paste, and then, the vati (tablet formulation) was also prepared (weight of each vati $=100 \mathrm{mg}$ ) [8].

Preparation of herbomineral formulation containing Hinguleswara rasausing Kajjali (HR2)

The required amounts of Hingulotha parada and Shuddha Gandhaka were triturated till the formation of Kajjali. Then, Kajjali (10 g), Shuddha Vatsanabha $(10 \mathrm{~g})$, and Pippali (10 g) were triturated together to form a homogeneous mixture. After that, the Bhavana procedure was followed with the addition of water into the produced homogenous mixture to form a semisolid paste, and then, the vati (tablet formulation) was also prepared (weight of each vati $=100 \mathrm{mg}$ ).

Preparation of herbomineral formulation containing Hinguleswara rasa using Kajjali (HR3)

The required amounts of Shuddha parada and Shuddha Gandhaka were triturated till the formation of Kajjali. Then, the Kajjali (10 g) was triturated along with Shuddha Vatsanabha (10 g) and Pippali (10 g) to form a homogeneous mixture. Then, the Bhavana procedure was followed with the addition of water into the produced homogeneous mixture to form a semisolid paste, and then, the vati was also made having the $100 \mathrm{mg}$ weight each.

Micrometric and organoleptic characterizations of herbomineral formulations

The basic properties such as color, odor, shape, and diameter of all three herbomineral-based vati were evaluated either visually or using vernier caliper. The various micromeritic characteristics (bulk density, true density, and Carr's index) of ingredients used to prepare these three herbomineral formulations were determined by following the standard methods mentioned in pharmacopoeial text [35].

\section{Evaluation of Hinguleswara rasa vati (tablet)}

The prepared vatis (tablets) were evaluated for appearance, weight variation, thickness, hardness, friability, and disintegration time as per pharmacopoeial standard methods. Disintegration time was measured in triple distilled water at $37 \pm 1^{\circ} \mathrm{C}$ using a tablet disintegration test apparatus. The tablets were considered as completely crumbled when all particles pass through the wire mesh represented in Table $2[35,36]$.

Solubility determination for herbomineral formulations

One gram of the formulation was mixed in $10 \mathrm{ml}$ of the solvents in a beaker. If the sample did not dissolve, then another $10 \mathrm{ml}$ of solvent was further added into the beaker. Only visual observations were made to see whether or not the tested formulations were dissolved slightly and sparingly.

Table 1: Quantity of Hingula before and after Shodhana

\begin{tabular}{lllll}
\hline Ingredients & $\begin{array}{l}\text { Quantity of Nimbu swarasa for Bhavana } \\
\text { (ml) }\end{array}$ & Time consumed for mardana samskara (h) & \multicolumn{2}{l}{ Weight after processing } \\
\cline { 4 - 6 } & & 5 & 302 & 2 \\
In (g) & Gained amount in (g) \\
\hline 300 g Hingula & 50 & 4.5 & 303 & 1 \\
& 50 & 5 & 306 & 3 \\
& 50 & 5.5 & 309 & 3 \\
\\
50 & 6 & 6 & 310 & 3 \\
& 50 & 6 & 315 & 2 \\
\hline
\end{tabular}

Table 2: Evaluation of Hinguleswara rasa vati (tablet)

\begin{tabular}{lllllll}
\hline Formulations & Weight variation (\%) & Hardness $\mathbf{( k g / \mathbf { c m } ^ { 2 } )}$ & Friability (\%) & Disintegration time & $\mathbf{p H}$ & Total ash value (w/w \%) \\
\hline HR1 & 4.80 & $3.00 \pm 0.5$ & 0.19 & $16 \min 49 \mathrm{~s}$ & 7.0 & 7.6 \\
HR2 & 5.84 & $2.50 \pm 0.5$ & 0.29 & $11 \min 49 \mathrm{~s}$ & 7.0 & 7.2 \\
HR3 & 3.92 & $2.50 \pm 0.5$ & 0.19 & $12 \min 30 \mathrm{~s}$ & 7.0 & 7.2 \\
\hline
\end{tabular}


In vitro antioxidant activity

Accurately weighed $5 \mathrm{~g}$ of each sample was taken in a conical flask and add $100 \mathrm{ml}$ of ethanol. The wort was occasionally shaken for $8 \mathrm{~h}$ and kept undisturbed for $16 \mathrm{~h}$. Then, the solvent was evaporated using water bath and the extract made by scratching off surface adherent. About $0.004 \%$ solution of DPPH is used as control or stock solution. First, $4 \mathrm{mg}$ of DPPH was dissolved in $100 \mathrm{ml}$ methanol. Then, the solution was incubated in dark for $5 \mathrm{~h}$ in a stoppered flask covered with aluminium foil at room temperature. $50 \mathrm{mg}$ sample extracts was dissolved in $50 \mathrm{ml}$ of methanol to get a concentration of $1 \mathrm{mg} / \mathrm{ml}$. Then, further dilutions were made at the concentrations of $20 \mu \mathrm{g}, 40 \mu \mathrm{g}, 60 \mu \mathrm{g}, 80 \mu \mathrm{g}$, and $100 \mu \mathrm{g} .50 \mathrm{mg}$ of Ascorbic acid was dissolved in $50 \mathrm{ml}$ of methanol to get a concentration of $1 \mathrm{mg} / \mathrm{ml}$. Then, further dilutions were made at the concentrations of $20 \mu \mathrm{g}, 40 \mu \mathrm{g}, 60 \mu \mathrm{g}, 80 \mu \mathrm{g}$, and $100 \mu \mathrm{g}$ and used as standard. First, the sample and standard solutions whose absorbance is to be checked are taken $3 \mathrm{ml}$ for each dilution and mixed with $3 \mathrm{ml}$ of $0.004 \%$ DPPH solution. Then, mixture was kept in test tube and covered with aluminium foil as the solvents are photosensitive and incubated for $1 \mathrm{~h}$. Then, the absorbance of both standard and test samples was checked at $517 \mathrm{~nm}$ with $0.004 \% \mathrm{DPPH}$ solution in methanol as control [22-25].

\section{In vitro anti-inflammatory activity checking}

The anti-inflammatory activity of Hinguleswara rasa was studied using inhibition of albumin denaturation technique as shown by Mizushima and Kobayashi and Sakat et al. minor modifications [9, 12, 25, 28]. The reaction mixture consists of test extracts and $1 \%$ aqueous solution of bovine albumin fraction, and $\mathrm{pH}$ of the reaction mixture was adjusted using small amount of $1 \mathrm{~N} \mathrm{HCl}$. The sample extracts were incubated at $37^{\circ} \mathrm{C}$ for $20 \mathrm{~min}$ and then heated to $51^{\circ} \mathrm{C}$ for $20 \mathrm{~min}$, after cooling the samples, the turbidity was measured at $660 \mathrm{~nm}$ (ultraviolet visible spectrophotometer). The experiment was performed in triplicate. The percentage inhibition of protein denaturation was calculated as follows: Percentage inhibition $=($ Abs Control - Abs Sample $) \times 100 /$ Abs control .

\section{RESULT AND DISCUSSION}

The organoleptic characteristics of all the formulations are shown in Table 3 while the results of various micromeritic characteristics of the ingredients used in all three herbomineral formulations are represented in Table 4.

The vati prepared based on various Hinguleswara rasa (HR1, HR2, and HR3) was subjected for various analytical parameters, and the results

Table 3: Organoleptic characters of vatis

\begin{tabular}{llll}
\hline Characteristics & HR1 & HR2 & HR3 \\
\hline Color & Light reddish orange & Dark black & Dark black \\
Odor & Slight aromatic & Odorless & Odorless \\
Shape & Small sphere & Small sphere & Small sphere \\
Diameter $(\mathrm{mm})$ & 3.5 & 3.5 & 3.5 \\
\hline
\end{tabular}

are shown in Table 2. All the parameters were passed by each of the formulation, and hence, the quality of the product to be screened was assured to be quality to produce therapeutic efficacy.

The content of each formulation was expected to be marginally similar which is evident from the results obtained from weight variation. Hence, there may not be any scope of contamination or adulteration. Although the flow property of HR1 was found to be marginally better than the other two formulations, this might lead to comparatively rapid disintegration and dissolution than the other two formulations (HR2 and HR3)

Fig. 1 shows the results of DPPH study. It was found that the Hinguleswara rasa (HR1) has comparatively more radical scavenging activity than the other two modified versions of Hinguleswara rasa by replacing Shuddha Hingula with Kajjali made from Hingulotha parada and Sodhita parada (HR2 and HR3, respectively). The difference of radical scavenging activity was marginal between HR2 and HR3 which was being expected depending on the fact that both of them are having Kajjali as their core ingredient, but the formulation HR2 is having a slight high as the Kajjali incorporated in it includes Hingulotha parada rather than suddha parade.

The results of solubility of three different herbomineral formulations in various solvents are represented in Table 5.

The tested three different formulations were shown significant inhibition of albumin denaturation at different concentrations (Table 6). At $800 \mu \mathrm{g} / \mathrm{ml}, \mathrm{HR} 1, \mathrm{HR} 2$, and HR3 were shown the values of percentage inhibition for protein denaturation 85.92 \pm 1.38 , $82.93 \pm 1.21$, and $83.92 \pm 1.32$, respectively. The $\mathrm{IC}_{50}$ value was found to be $288.04 \pm 2.78 \mu \mathrm{g} / \mathrm{ml}$ in albumin denaturation while aspirin showed the maximum inhibition.

Values represent in the results are mean \pm SD of three replicates; linear regression analysis was used to calculate $\mathrm{IC}_{50}$ value.

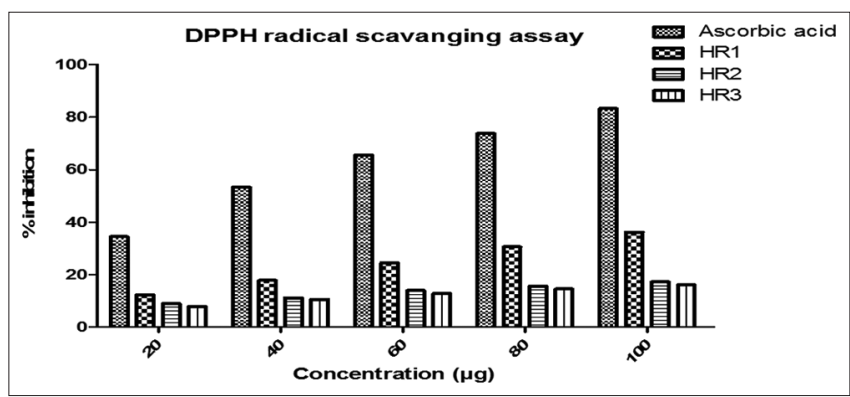

Fig. 1: The percentage free radical inhibition observed for three different herbomineral formulations along with standard drug at various concentration levels

Table 4: Micromeritic characteristics of powders used to prepare vatis

\begin{tabular}{llllll}
\hline Test samples & Bulk density & Tapped density & Carr's index & Hausner ratio & Angle of repose $(\theta)$ \\
\hline HR1 & 0.46 & 0.55 & 16.36 & 1.19 & 34.29 \\
HR2 & 0.42 & 0.53 & 20.75 & 1.26 & 36.12 \\
HR3 & 0.41 & 0.47 & 12.76 & 1.14 & 35.18 \\
\hline
\end{tabular}

Table 5: Solubility of herbomineral formulations in different solvents

\begin{tabular}{lll}
\hline Solvent/Sample & HR1 & HR2 \\
\hline Water & Sparingly soluble & Sparingly soluble \\
Chloroform & Slightly soluble & Slightly soluble \\
Hydrochloric acid & Sparingly soluble & Sparingly soluble \\
Ethanol & Slightly soluble & Slightly soluble \\
\hline
\end{tabular}


Table 6: In vitro anti-inflammatory activities determined for tested three different Hinguleswara rasa-based herbomineral formulations along with aspirin standard through albumin denaturation bioassay

\begin{tabular}{|c|c|c|}
\hline \multirow[t]{2}{*}{ Sample } & \multirow{2}{*}{$\begin{array}{l}\text { Dilutions } \\
(\mu \mathrm{g} / \mathrm{ml})\end{array}$} & \multirow{2}{*}{$\begin{array}{l}\text { Inhibition (\%) } \\
\text { Albumin denaturation }\end{array}$} \\
\hline & & \\
\hline \multirow[t]{6}{*}{ HR1 (Test) } & 50 & $23.70 \pm 1.48$ \\
\hline & 100 & $33.82 \pm 1.13$ \\
\hline & 200 & $48.88 \pm 0.71$ \\
\hline & 400 & $65.43 \pm 1.13$ \\
\hline & 600 & $76.54 \pm 0.85$ \\
\hline & 800 & $85.92 \pm 1.38$ \\
\hline \multirow[t]{6}{*}{ HR2 (Test) } & 50 & $22.70 \pm 1.40$ \\
\hline & 100 & $31.82 \pm 1.10$ \\
\hline & 200 & $46.88 \pm 0.75$ \\
\hline & 400 & $63.43 \pm 1.12$ \\
\hline & 600 & $74.54 \pm 0.80$ \\
\hline & 800 & $82.92 \pm 1.21$ \\
\hline \multirow[t]{6}{*}{ HR3 (Test) } & 50 & $21.70 \pm 1.48$ \\
\hline & 100 & $32.82 \pm 1.13$ \\
\hline & 200 & $46.88 \pm 0.74$ \\
\hline & 400 & $62.43 \pm 1.13$ \\
\hline & 600 & $74.54 \pm 0.76$ \\
\hline & 800 & $83.92 \pm 1.32$ \\
\hline $\begin{array}{l}\text { Correlation coefficient } \\
\text { value }(r)\end{array}$ & - & 0.946 \\
\hline $\mathrm{IC}_{50}$ value $(\mu \mathrm{g} / \mathrm{ml})$ & & $288.04 \pm 2.78$ \\
\hline \multirow[t]{2}{*}{ Aspirin (standard) } & 100 & $67.45 \pm 0.64$ \\
\hline & 200 & $75.89 \pm 0.56$ \\
\hline
\end{tabular}

\section{CONCLUSION}

Hinguleswara rasa is a herbomineral formulation documented to have a potent anti-rheumatic activity. It comprises mainly three ingredients, i.e. Shuddha Hingula, Shuddha Vatsanabha, and Pippali. Here, a comparative study was done with another two different types of HR but with slightly different composition. It could be concluded that the changes made in the formulations did not affect the in vitro anti-inflammatory and antioxidant effects of the herbomineral formulations.

\section{REFERENCES}

1. Govinda D. Bhaishajya Ratnavali Edited by Ambikadatta Shastri. 11th ed. Varanasi: Published by Choukhamba Sanskrit Samsthana; 1996.

2. Chudamani V, Rasakamadhenu. In: Acharya S, editor. Gularaja Sharma Mishra. $2^{\text {nd }}$ ed. Varanasi: Choukhamba Orientalia; 1999.

3. Indradeva T. Rasendra Sara Sangraha edited by Siddhinandana Mishra. 3rd ed. Varanasi: Published by Choukhamba Orientalia; 2003.

4. Reddy K, Chandra R. Text Book of Rasashastra. 1st ed. Varanasi: Chaukhambha Sanskriti Bhavan; 2007.

5. Siddhinandan M. Ayurvediya Rasashastra. $11^{\text {th }}$ ed. Varanasi: Chaukhambha Orientaliya; 2001.

6. Chandrabhushan Z. A Text book of Rasashastra. Revised Edition. Varanasi: Chaukhambha Surbharti Prakashan; 2007.

7. Acharya TY. Rasamritam, Transalated by Damodar Joshi. 1st ed. Varanasi: Chaukamba Sanskrit Bhavan; 1998.

8. Sadananda S, Rasatarangini, Edited by Kashinatha Shastri. 11th ed. Varanasi: Motilala Banarasi Das, 24th Taranga; 1979.

9. Sakat S, Juvekar AR, Gambhire MN. In vitro antioxidant and antiinflammatory activity of methanol extract of Oxalis corniculata Linn. Int J Pharm Pharmacol Sci 2010;2:146-55.

10. Tortora GJ, Reynolds S, editors. Principles of Anatomy and Physiology. $7^{\text {th }}$ ed. New York: Harper Collins College Publishers; 1993. p. 695.

11. Sadique J, Chandra T, Thenmozhi V, Elango V. The anti-inflammatory activity Enicostemma littorale and Mullogo cerviana. Biochem Med Metab Biol 1987;37:167-76.
12. Mizushima Y, Kobayashi M. Interaction of anti-inflammatory drugs with serum preoteins, especially with some biologically active proteins. J Pharm Pharmacol 1968 20:169-73.

13. Azeem AK, Dilip C, Prasanth SS, Junise V, Shahima H. Antiinflammatory activity of the glandular extracts of Thunnus alalunga. Asia Pac J Med 2010;3:412-20.

14. Gandhidasan R, Thamaraichelvan A, Baburaj S. Anti-inflammatory action of Lannea coromandelica by HRBC membrane stabilization. Fitoterapia 1991;63:81-3.

15. Mahajan A, Tandon VR. Antioxidants and rheumatoid arthritis. J Ind Rheumatol Assoc 2004;12:139-42.

16. Shenoy S, Shwetha K, Prabhu K, Maradi R, Bairy KL, Shanbhag T. Evaluation of anti-inflammatory activity of Tephrosia purpurea in rats. Asian Pac J Trop Med 2010;3:193-5.

17. Leelaprakash G, Dass SM. In vitro anti-inflammatory activity of methanol extract of Enicostemma axillare. Int J Drug Dev Res 2011;3:189-96.

18. Smith HS, Smith AR, Seidner P. Painful rheumatoid arthritis. Pain Physician 2011;14:E427-58.

19. McInnes IB, Schett G. The pathogenesis of rheumatoid arthritis. N Engl J Med 2011;365:2205-19.

20. Gabriel SE. The epidemiology of rheumatoid arthritis. Rheum Dis Clin N Am 2001;27:269-81

21. Weyand CM, Goronzy JJ. Pathogenesis of rheumatoid arthritis. Med Clin North Am 1997;81:29-55.

22. Umamaheswari M, Chatterjee TK. In vitro antioxidant activities of the fractions of Coccinia grandis L. leaf extract. Afr J Trad Complementary Altern Med 2008;5:61-73.

23. Gonzalez-Juanatey C, Vazquez-Rodriguez TR, Miranda-Filloy JA, Gomez-Acebo I, Testa A, Garcia-Porrua C, et al. Anti-TNF-alphaadalimumab therapy is associated with persistent improvement of endothelial function without progression of carotid intima-media wall thickness in patients with rheumatoid arthritis refractory to conventional therapy. Mediators Inflamm 2012;2012:674265.

24. Cheeseman KH, Slater TF. An introduction to free radical biochemistry. In: Cheeseman KH, Slater TF, editors. Free Radical in Medicine. New York: Churchill Livingstone; 1993. p. 481-93.

25. Mitchell RN, Cotran RS. Cell injury, adaptation, and death. In: Kumar V, Cotran RS, Robbins SL, editors. Robbins Basic Pathology. $7^{\text {th }}$ ed. New Delhi: Harcourt (India) Pvt. Ltd.; 2003. p. 3-33.

26. Rangan U, Bulkley GB. Prospects for treatment of free radical-mediated tissue injury. In: Cheeseman KH, Slater TF, editors. Free Radicals in Medicine. New York: Churchill Livingstone; 1993. p. 700-18.

27. Ozkan Y, Yardým-Akaydýn S, Sepici A, Keskin E, Sepici V, Simsek B, et al. Oxidative status in rheumatoid arthritis. Clin Rheumatol 2007;26:64-8

28. Lunec J, Halloran SP, White AG, Dormandy L. Free radical oxidation (peroxidation)products in serum and synovial fluid in rheumatoid arthritis. J Rheumatol 1981;8:233-45.

29. Remans PH, van Oosterhout M, Smeets TJ, Sanders M, Frederiks WM, Reedquist KA, et al. Intracellular free radical production in synovial $\mathrm{T}$ lymphocytes from patients with rheumatoid arthritis. Arthritis Rheumatol 2005;52:2003-9.

30. Jaswal S, Metha HC, Sood AK, Kaur J. Antioxidant status in rheumatoid arthritis and role of antioxidant therapy. Clin Chim Acta 2003;338:123-9

31. Hagfors L, Leanderson P, Skoldstam L, Anderson J, Johanson G. Antioxidant intake, plasma antioxidants and oxidative stress in a randomized, controlled, parallel, Mediterranean dietary intervention study on patients with rheumatoid arthritis. Nutr J 2003;2:5.

32. Pillai CK, Pillai KS. Antioxidants in health. Indian J Physiol Pharmacol 2002:46:1-5

33. Samhita S. Dipika Hindi commentary. In: Tripathi B, editor. Madhyam Khand. Varanasi: Chaukhamba Subharti Prakashan; 2008.

34. Rasavagbhata S, Samuchaya R. In: Tripati ID, editor. Sloka 152-153. $2^{\text {nd }}$ ed. Ch. 3. Varanasi: Chaukamba Sanskrit Prakashan; 2003.

35. Lachman L, Lieberman HA, Kanig JL. The Theory and Practice of Industrial Pharmacy. $3^{\text {rd }}$ ed. Mumbai: Verghese Publishing House; 1987.

36. Odeku OA, Itiola OA. Effects of interacting variables on the tensile strength and the release properties of paracetamol tablets. Trop J Pharm Res 2003;2:147-53. 